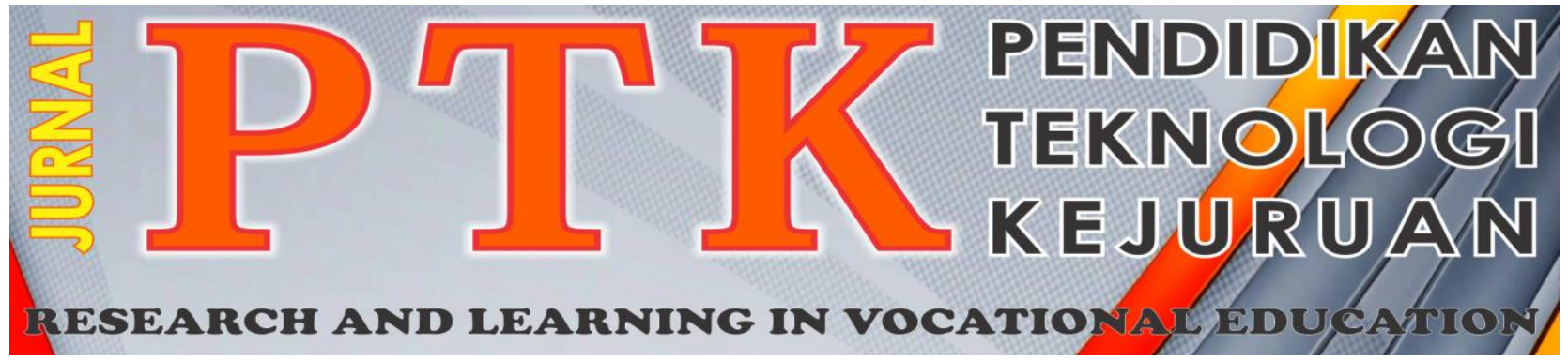

Vol. 2, No. 4, 2019

P-ISSN: 2621-3273

E-ISSN: 2621-1548

\title{
Perceptions of Workplace, Principal, and Productive Teachers on Students' Work Readiness in SMK Negeri 5 Surabaya Indonesia
}

\author{
Subijanto \\ Center for Policy Research on Education and Culture, \\ The Office of Educational Research and Development \\ "Corresponding author, e-mail: subijanto2012@gmail.com
}

\begin{abstract}
Work readiness of Vocational School (SMK) students will not be formed by itself, but through learning outcomes obtained inside and outside the school in the form of industrial work practices. This is necessary as the practical facilities in Vocational High Schools are inadequate and thus have an impact on the quality of graduates' competencies. One policy of the Directorate of Vocational School is that students are required to take part in the program in the workplace/industry in a certain period of time. This study aims to examine the work readiness of graduates of SMK Negeri 5 Surabaya on the competency of Building Drawing Engineering based on perceptions of the workplace, principals, and productive teachers. Data collection method is conducted through focus group discussion. The results of the study show that graduates of Building Drawing Engineering of that school are ready to work according to their competencies. This study concluded that graduates of Building Drawing Engineering in SMK Negeri 5 Surabaya are ready to work because they are supported by 6 to 9 months internship. Therefore, they have 1) sufficient industrial practice experiences; (2) adequate level of basic competency mastery; and 3) highly potential work adaptation.
\end{abstract}

Keywords： work readiness, vocational high school (SMK) 5 Surabaya, building drawing engineering competency

\section{INTRODUCTION}

The goal of a vocational high school (SMK) is to produce middle-level technician graduates who are ready to work in certain fields and can continue to higher education [1]. To produce qualified SMK graduates in accordance with the needs of the job market, cooperation with the business and industrial world (DU/DI) is needed. Therefore, learning is conducted at school and outside the school. The existence of carrying capacity in vocational high schools (SMKs), particularly practical infrastructure is insufficient and the quality of teachers is generally less competent. Outside-school learning through industrial work practices (internship) is absolutely necessary. Directorate of Vocational School has made a number of efforts to improve the quality of vocational school graduates. However, the absorption rate of SMK graduates by the labor market is still low. BPS data [2] show that vocational school graduates still have a higher level of open unemployment compared to graduates from other educational level [2]. The inconsistency between the workplace and the quality of vocational school graduates is one of the factors that drives the low absorption of vocational graduates in the workplace.

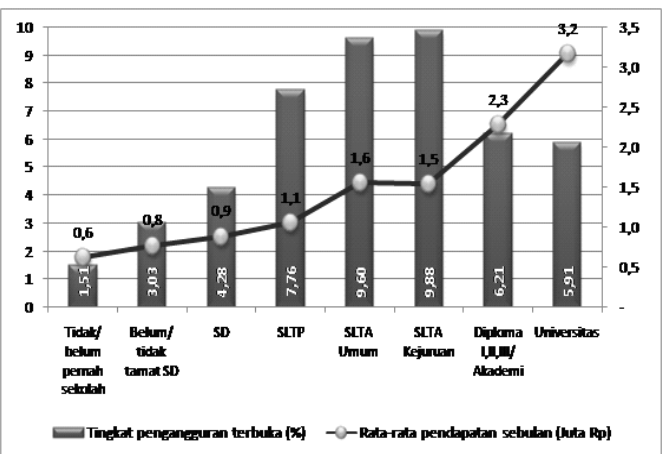

Source: BPS [2] (http://www.bps.go.id/ menutab.php?

This phenomenon indicates that SMK graduates have not yet met the expectations of the workplace. The high unemployment rate of SMK graduates shows the quality of vocational education that is less 
relevant to the needs of the industrial world. The symptoms of this gap are caused by various things, including a) vocational education almost and even fully tends to be organized by schools; and b) vocational education is less able to adjust to changes and developments in the needs of the workplace so that the work readiness of vocational graduates becomes a determining factor. The completeness and quality of learning facilities in SMKs influence the quality of graduates. Therefore, learning facilities and infrastructure must meet the needs of teachers and students in order to support achieving the goals. [3] In other words, better facility fulfillment in the learning process in SMK will support the improvement of students' competency skill in meeting industrial needs.

Empirical facts show that the implementation of vocational teaching and learning is still experiencing major problems, they are 1) not all skills competencies opened in SMKs are in accordance with the needs of the industry or the needs of the surrounding community; 2) graduates' competency level is not all in accordance with the standards required by the industry; 3) competent graduates have not received official recognition in the form of competency certificates; 4) lack of information to the industry about skill competency held at Vocational High Schools; 5) lack of information about needs and opportunities of jobs for vocational graduates in the industry; 6) not all regulations support the development of SMKs; and 7) lack of related party support for the development of SMK [4].

In the efforts to improve the quality of SMK graduates according to the needs of DU/DI, the Minister of Education and Culture (at that time Wardiman Djojonegoro) gradually implemented the dual system philosophy (link and match). However, it experienced ups and downs so that the link and match linkages between competencies and qualifications of SMK graduates and competencies of DU/DI needs have not been optimally achieved. Efforts to strengthen cooperation between the Ministry of Education and Culture, the provincial government that manages SMKs and industries as partners need to be intensified so that the students' and teachers' competency through internship or teacher functional trainings is carried out proportionally in the industry and in technopark [5].

In addition, it is necessary to synchronize vocational curriculum so that graduate competencies are linked and matched with the competencies needed by the workplace (industry) so as to minimize the gap between competencies acquired in schools and technologies used in industry [6]. This also creates a link and match with the employment program [7].

Vocational education and training (VET) are seen as a solution of unemployment problems [8]. VET is considered an effective way of supplying the needs of skilled workforce, as an option other than general high education for students who are weak in academics, as a solution to increase opportunities for young people who lack in the cost, expertise, or motivation to continue to higher education level. This is a way to increase life expectancy for those who have not received work and for those with disabilities [9].

The existence of VET program is still a debate in many developing countries [10]. However, the success of VET is important to consider in the development strategies of developing countries. Therefore, this program is able to prepare individuals with expertise needed by the industry and also help reduce unemployment. [9] Besides being able to provide skills to prospective workers in the form of expertise needed by the workplace, VET is also important for increasing productivity and employment opportunities for internal sector workers [10].

In order to support the success of VET program, companies contributing to the program shall be given incentives from the government [11]. The strong relationship between vocational education institutions and graduate users (industry) must be formed legal. Educational and industrial institutions will mutually benefit if the training provider institutions hold qualification training that is also valuable and needed by the workplace [3]. He stated that proper learning of vocational education is combining vocational basic theories and industrial practices to realize the link and match of the world of education and industry. Furthermore, they argued that this is an effort to increase the relevance between vocational education and technological developments in the industry [12] and [13].

Students' experiences during internship (what students have experienced) is very important to note how their experiences (how they learn from those experiences when involved in work and what they learned) serve as a preparation of work readiness in the future [14].

SMK curriculum, in addition to containing soft skills (behavior, motivation, creativity, discipline, and others) programs, also contains hard skills (competency skills). Further, DU/DI treats internship students as workers properly through an industrial culture approach, which means that DU/DI must not treat students only as internship students, but must also be guided in doing work in the industry (given trust and work responsibilities), so that eventually 
students have work experiences to support their work readiness and have work satisfaction 15].

Research results [16] show that the implementation of SMKs tends to 1) be less optimal in the consistency between graduate competencies and the workplace; 2) be weak in preparing graduates to become entrepreneurs; 3 ) be unable yet to provide certainty/guarantee for graduates to obtain decent jobs; 4) be slow in responding to the dynamics of demands for economic development; and 5) to have a single function, namely preparing students to work in certain fields as employees.

Minister of Education and Culture, Muhajir Effendi, paid serious attention to strengthening the implementation of the dual system philosophy in SMKs as he emphasized in order to prepare qualified human resources. Furthermore, he affirmed that "the focus of vocational education" must be based on the skill competence it owns (link and match between the world of education and DU/DI). $\mathrm{He}$ is optimistic that "we believe, SMKs are capable of creating competent human resources according to labor market needs". [17 ] Therefore, link and match is a policy that must be applied in vocational education to produce high quality and highly competitive vocational graduates [18].

SMK Negeri 5 Surabaya has various programs and skill competencies, one of which is the competency of Building Drawing Engineering (TGB). The duration of study is for 4 (four) years, with details of theoretical and basic practical learning for 3 (three) years and in the $4^{\text {th }}$ year doing industrial internship.

Based on the background and the problem above, this research question is What are the perceptions of DU/DI, principal, and productive teachers on the work readiness of Building Drawing Engineering skill competency in SMK Negeri 5 Surabaya? Thus, the purpose of this study is to examine the perceptions of DU/DI, principal, and productive teachers on the work readiness of graduates of SMK 5 Surabaya in Building Drawing Engineering skill competencies.

\section{LITERATURE REVIEW}

\subsection{Perceptions and Work Readiness}

According to [18], perception is a process that involves the entry of messages or information into the human brain Meanwhile, perception is a process that begins through a sensing process, namely the process of receiving a stimulus by an individual through sensory devices or sensory processes which are then passed on to the process of perception [19]. From these definitions, it can be concluded that perception is a process related to the entry of messages or information into the human brain which is then manifested into certain opinions about an object. The object referred to in this case is the perception of DU/DI, principal, and productive teachers on the graduates of SMK 5 Surabaya in TGB skill competence.

Furthermore, work readiness is defined as a "process to achieve a goal involving the work development of students which includes attitudes, values, knowledge and skills" [20]. Meanwhile, other opinions argue that work readiness is defined as the overall condition of individuals which includes physical, mental and experience maturity and the willingness and ability to carry out a job or activity [21]. From these two opinions, it can be concluded that work readiness is an ability that shows the harmony between the maturity of physical and mental and learning experiences that must be possessed by SMK graduates. Students' work readiness will not be formed by itself, but through learning outcomes obtained at school and at DU/DI through internship. There is a very strong relationship between interests and career choices on students' work readiness [22].

As prospective workforces, SMK students' work readiness is an individual condition from the combination of basic practices in school and the internship results during a certain period of time. Internship at 3-year SMKs (SMKN 7 Surabaya) is carried out for one to three months, while 4-year SMKs (SMKN 5 Surabaya) is conducted for six to nine months.

\subsection{Industrial Work Practice (Prakerin)}

One of the Government's efforts to improve the quality of SMK graduates is to optimize the theoretical learning and basic practices in schools and vocational practice learning in DU/DI (dual system). In its essence, internship is a practice/training program held in the field (DU/DI) in a series of learning activities as an integral part of the SMK education program [23]. Thus, internship is believed to have a positive correlation with SMK graduates' work readiness.

Internship becomes one of the supporting programs for implementing SMKs in an effort to produce qualified prospective workforces. From time to time, Dit. P2SMK continues to refine the program to implement industrial work practices so that the link and match of education between SMK and DU/DI can be realized according to its goal. Prakerin or intership is one implementation form of professional skill education, which systematically and synchronously integrates school education and skills mastery programs obtained through direct 
working activities in the industry, towards achieving a certain professional level [24].

In addition, internship can be interpreted as a training model held in job field, aiming at providing the abilities needed in certain skills, according to the required demands in a specific profession. Therefore, the skill competence obtained at school can be improved as a preparation for work readiness as well as having a) confidence to work; $b$ ) work motivation, and c) the ability to socialize in a working environment. In other words, internship is a curricular activity that provides opportunities for SMK students to adapt with the real busines world, so that they have better work readiness after they graduate [28]. This is in line with an opinion that the implementation of internship can improve personality development. [25]

The implementation of internship for students is intended to 1) produce professional workforces, i.e. workers who have an appropriate level of knowledge, skills and work ethic in accordance with the demands of the business world; 2) increase the link and match between educational institutions and the industrial world; 3) improve the efficiency of providing qualified education and work training by utilizing training resources in the industrial world; and 4) provide recognition and appreciation of work experiences as part of the education process [26].

The importance of work experiences in shaping students' work readiness is reflected in students' participation in the internship program [31]. Furthermore, their ability to meet job requirements in this case work readiness depends on several factors such as industrial training. This is important for developing students in balance based on job needs. The experiences gained during internship will benefit them that they will be more mature in preparing themselves for work as the internship experiences provide the preparation of work needed in the workplace. [27]

Information on the workplace can influence one's decision making in determining his/her future career. The information on the workplace obtained by students is expected to be an illustration in seeing and facing existing business opportunities. This information can be obtained from various sources, both from school through career guidance and from DU/DI. For SMK students having a lot of information about the workplace, it will be easier to find out about the condition of the workplace and the requirements for entering the work. This can encourage students to further improve their work readiness so they can work in accordance with their fields of expertise. In addition to internship and information on the workplace, students' readiness also needs to pay attention to the motivation to enter the workplace to encourage work spirit. Motivation is needed by students in working so that when they work, they will feel happy in carrying out their duties. [28]

Students' selection of the career fields is influenced by various factors, including individual factors, individual interests, environmental factors and personal relationships. Basically, career selection is mostly done because of the desire in the selection of a specific field of work, experience and practice in the learning process so that they can understand the desired field of work in preparation for entering the workplace [29].

The results of the study show that efforts to produce workforces who have high work readiness will be achieved if graduates have high maturity or mastery which can be seen from thir experiences and work practices in the industry [30]. The results of the study are in line with research that shows that there is a high relationship between industrial work practice experiences with students' work readiness [31].

In contrast to the results of the study [32], there is a low influence between internship and students' work readiness in relation to the internship experiences to students' work readiness as prospective employees. Basically information on the workplace consists of facts about professions, position or careers and aims to help individuals gain views, understanding and insight of the workplace and its aspects [33]. Information on the workplace that includes all data on the types of jobs that exist in the community, regarding the stages and types of positions, the classification system of positions and future prospects related to the real needs of the community for certain types of work;

Motivational process is largely directed at meeting and achieving needs Motivation arises due to the desire to do activities, the presence of encouragement and the need to carry out activities, the existence of hopes and ideals, the existence of a decent environment, the existence of interesting activities and the existence of appreciation and respect for oneself [34]. Furthermore, he explained that work motivation is one of the factors that determine a person's performance. The extent of the effect of motivation on a person's performance depends on how much intensity the motivation is given.

I Made Sirsa's research [35] found that there was a significant relationship between students' work motivation towards students' work readiness. This means that the better the contribution to students' work motivation, the better the students' 
work readiness. In contrast, according to Tan Shen Kian, work motivation and job satisfaction are closely related to various motivational theories but both are different, work motivation and job satisfaction are not identical with each other. This means that work motivation is not always related to job satisfaction [36].

\subsection{Industrial Work Practice/Internship}

Viewed from the aspect of benefits, Yuli [39] (2012) argues that the implementation of internship has benefits for various parties, including students, schools, and DU/DI. For students, the benefits of internship are 1) the learning outcomes of internship students will be more meaningful, because after graduation, they will truly have skills that leads to professional as a basis for continuous personal development; 2) professional skills obtained can improve self-esteem and confidence, so that it will encourage professionalism at work. For schools (SMKs) internship is beneficial for 1) the goal of education to generate professional skills for students can be achieved; and 2) giving satisfaction to the school education, because the graduates are guaranteed to get benefits both in the workplace and in the society. For DU/DI, the benefits of apprenticeship include 1) companies can get to know the quality of internship students who learn in their industry; 2) internship students are prospective workforces who benefit the industry; 3) companies can assign tasks to internship students for the interests of the company according to their competencies; 4) internship students are easier to control in terms of discipline in the form of compliance with company rules; and 5) giving satisfaction to the industry due to recognition of participation to decide the future of the students through internship [37].

Yuli's opinion is in line with the provisions of the Directorate of PSMK (2016b) which formulated several benefits of internship for various parties as follows. Internship for students, are useful for 1) applying and improving the knowledge that has been obtained at school; 2) adding insight into the workplace, a positive work climate that is oriented towards caring for the quality of processes and work outcomes; 3) adding and improving competencies and can instill a high work ethic; 4) having productive abilities in accordance with skill competencies learned in the internship/prakerin place; and 5) developing their abilities in accordance with the guidance/direction of the industry supervisor. Furthermore, internship for schools are beneficial to 1) establish mutually beneficial cooperative relations between schools and the workplace; 2) improve the quality of graduates through work experiences during internship; 3) develop school programs through curriculum synchronization, learning processes, teaching factories, and the development of practical facilities and infrastructures based on the results of observations in industrial workplaces; and 4) improve the quality of graduates.

Some previous studies that are relevant to work readiness to TGB SMK graduates are as follows. First, [38] conducting a study on work readiness and the subject of Drawing through Software in TGB (drafter) competency program at SMK Negeri 5 Surabaya showed that 1) learning outcomes of the subject of drawing with software and internship values can influence the value of work readiness; and 2) internship affects work readiness. Second [39]; the study of the effect of internship on the work readiness of the XII class TGB competency program in SMK 6 Malang indicates that 1) class XII students of TGB are good enough in carrying out industrial work practices; and 2) the class XII work readiness in SMKN 6 Malang can be categorized as good. Third [40]. Research on the effect of productive subjects, internship, and family economic conditions on the students' work readiness class XI, SMKN 4 Semarang concluded that there are effects of productive subject achievement, internship, and family economic conditions on TGB students' work readiness in SMKN 4 Semarang both simultaneously and partially. Fourth [41] evaluating the internship implementation of TGB Skill Competency in SMKN 2 Klaten, it shows that overall includes 1) input evaluation: (a) learners' readiness in a very good category; (b) the performance of productive-subject teachers in a very good category; (c) readiness of facilities and infrastructure in a very good category; 2) process evaluation indicates: (a) the performance of students in a very good category (b) the performance of the supervisor of industrial work practices in a very good category; and 3) product evaluation: students' work readiness in a very good category. Fifth [42] about the readiness of Class XI students in TGB Skill Competencies in SMKN 2 Depok in Facing the Workplace Academic Year shows that: 1) there is a positive and significant influence between motivation to enter the workplace and readiness to encounter the workplace, 2) positive and significant influence between the information on the workplace and the readiness to face work. Sixth [43] in the study of the work readiness of prospective graduates of SMK Islam 1 Blitar TGB skill competence in the world of Construction Services showed a) work readiness of graduates of SMK Islam TGB Skill Competence included in the criteria of good; and b) students carry 
out tasks according to the procedure, which is seen from the values obtained above the minimum value specified by the school.

Seventh [44] in a study "The Effect of Industrial Work Practices on the Work Readiness of Class XII Students in TGB Program in SMKN 1 Adiwerna Tegal Academic Year 2008/2009 shows that the majority of class XII students of TGB program at SMKN 1 Adiwerna Tegal have implemented industrial work practices with results very good and included in the criteria of very high. Eighth [45] conducting a case study on the Effect of Industrial Work Practices on the Work Readiness of Class XII Students of SMKN 5 Bandung on TGB skill competencies indicates that 1) in general the experiences of industrial work practices was largely included in the fairly good category; 2) work readiness of class XII students of SMKN 5 Bandung included in the fairly good category; and 3) the experiences of industrial work practices has a positive and significant effect on work readiness.

Based on some of the results of previous studies/research, it can be concluded that internship has a significant influence on work readiness of SMK students in TGB skill competence.

\section{II.METHOD}

The research on the students' work readiness of TGB skill competencies in SMKN 5 Surabaya is the development of research "A Development Study on 3(three)-year and 4 (four)-year Vocational High Schools". The sampling technique used purposive sampling where SMKN 7 Surabaya represented a three-year Vocational High School and SMKN 5 Surabaya represented four-year Vocational High Schools. This research was conducted in August to October 2016 by involving a number of respondents consisting of a) Head of Secondary Education in Surabaya District Education Office (1 person); b) Head of Secondary Education Curriculum Section of Surabaya District Education Office (1 person); c) Principals of SMKN 5 and 7 Surabaya (2 people); Vice Principals of Public Relations/Hubin of SMKN 5 and 7 Surabaya (2 people); d) TGB vocational/productive teachers in SMKN 5 and 7 Surabaya (2 people); e) Representatives of Partner Institution (DU/DI) of SMKN 5 and 7 Surabaya (4 people), and f) Fepresentative from Surabaya District Employment Office (1 person). The instrument for data collection uses questionnaires and forum group discussions. Data were analyzed in a descriptive manner.

\section{RESULTS AND DISCUSSION}

\subsection{Students' Work Readiness} skill competency in SMKN 5 Surabaya is supported by the students' internship experiences in the industry for an average of 9 months. The internship is carried out in class XIII after completing the national examination. This condition is supported by [25], [29], and [39] regarding the benefits of internshipand research by [38]; [39], [40]; [41]; [42], [43] , [44], and [45].

\subsection{Perceptions of Industry}

Industry perceptions of work readiness of TGB studens in SMKN 5 Surabaya indicate that the students' internship of SMKN 5 Surabaya is considered more appropriate than internship which is done by 3-year SMK students. Industrial experience accepts the two models of internship, the internship model of SMKN 5 Surabaya has advantages such as 1) students can improve their basic competencies as a whole so that they get the preparation of continuous personal development; 2) students are more ready to work because they have sufficient industrial work experiences; 3) students have confidence to socialize (adjust) to the work environment; 4) DU/DI is better able to get to know the quality of internship students; 5) it enables DU/DI to assign tasks to internship students for the company's interests according to their competencies; and 6) it provides industrial satisfaction because internship students can contribute to the production process in accordance with the mastery of competencies (results of FGDs). These conditions are in line with Yuli's opinion [3].

On the other hand, there are weaknesses in the 3-year SMK internship model, such as: a) when the internship students have not been given the theory and practice of calculating the cost and budget plan (RAB) estimation and calculating Volume. Ironically, when the internship students are given task to review the RAB and Volume with DU/DI team, they are not ready to do the task; b) during the 3-month internship, sometimes students have not yet reached a certain level of competence, and they have to go back to school; and c) students lose the repetitive opportunity to continue internship in the same place to achieve full competence.

\subsection{Perceptions of Principal}

The work readiness of SMKN 5 Surabaya students majoring in TGB has been prepared since the end of class X to the end of class XII through the formation of work attitudes (basic practices) and character guidance (such as discipline, accountability, and cooperation). This is aimed at 
keeping the school reputation and keeping the industry.

unharmed. Especially if an industry has willingness to accept students internship, the school will be ready to send their students according to specified requirements from the industry. The implementation of TGB student internship is not only in Surabaya and East Java in general but also abroad (Timor Leste). This indicates that the school collaboration with DU/DI as a school work partner has gained trust and mutual benefits. One example is the internsiop in Timor Leste is carried out at the request of several construction companies who are willing to be in charge of round-trip transportation from Surabaya to Timor Leste and accommodation during the internship. Furthermore, if construction companies require their new employees, they do their own recruitment directly to schools and even sometimes there are companies that offer students jobs after the internship is complete.

\subsection{Perception of Productive Teachers}

Before the students do internship, the school conducts work guidance and monitor the development of students. They area also given a work orientation for approximately 5 days by various relevant keyspeakers. In addition, students always keep updated about the developments their fields in accordance with information obtained from TGB productive teachers who have extra jobs outside of teaching hours as construction assistants, such as their experiences can be used as additional teaching materials/enrichment related RAB estimation material and calculation of the work volume. In fact, there is sometimes a novelty of building materials (the use of types of steel) used in construction, the teacher automatically adds them as enrichment materials for students. Another way that productive teachers do is to collaborate with DU about the "guest teacher program" where the industrial instructor teaches the students at school in a period of time (incidental) for enrichment in order to enhance students' competency.

\section{CONCLUSION}

Referring to the results and discussion, it can be concluded that DU/DI, principals, and productive teachers have the same perception of the work readiness of graduates of SMKN 5 Surabaya in Building Drawing Engineering competence. According to them, graduates of SMKN 5 Surabaya have more-ready-to-work Building Drawing Engineering skills than graduates of SMKN 7 Surabaya. The work readiness is supported by DU/DI, namely the experiences of students doing the internship for an average of 9 months. In addition, before the internship, students are prepared from the end of class $X$ related to the character and introduction of DU/DI by productive teachers. The students' work readiness has gained trust from many school work partners (DU/DI) so that a quite significant number of graduates are recruited as employees in construction companies.

\section{REFERENCES}

[1] Regulation of Government of Republic of Indonesia Number 17 of 2010, on the Management and Implementation of Education, Jakarta: Kemdiknas.

[2] Central Bureau of Statistics. 2013. Unemployment Rate in 2013, (Online), (http://www.bps.go.id/ menutab.php?tabel=1\&kat=1\&id_subyek-06, accessed on 31 March 2018

[3] J. Avis., Crossing Boundaries: VET, the Labour Market and Social Justice. International Journal for Research in Vocational Education and Training (IJRVET).5, (3, pp. 178-190, 2018), November 2018 https://doi.org/ 10.13152/IJRVET.5.3.2

[4] Directorate of Vocational School. Explanations from the Sub-Head of Directorate of Vocational School: Alignment of 2013 Curriculum with the Needs of Workplace Jakarta: Dikmenjnur. $2016 a$.

[5] Noor, I., and Waluyo, Heni. "A relevance of the implementation of vocational school (VS) towards the needs of industry and workforce and the use of technopark for training teachers and students of VS". International Journal of Vocational and Technical Education Research Vol.5, No.2, pp.1-23, April 2019.

[6] E. Suharno and Widiastuti, "The Development of Implementation Standard of Practical Working in Industries of VS students Technical Machine Programme in Surakarta (A Case Study)". Journal of Educational Technical Programme. Homepage:

https://jurnal.uns.ac.id/jptk.JIPTEK, Vol. X No. 1, January 2017.

[7] McCartney, John, and Paul Teague. 2001. "Private-sector Training and the Organization of the Labour Market: Evidence from the Republic of Ireland in Comparative Perspective." The International Journal of Human Resource Management 12 (5): pp.772799, 2001.

[8] Eichhorst, Werner, Núria Rodríguez-Planas, Ricarda Schmidl, and Klaus F. Zimmermann. 
"A Road Map to Vocational Education and Training in Industrialized Countries." ILR Review 68 (2): pp. 314-337, 2015.

[9] O.M. Oketch., "To Vocationalise or Not to Vocationalise? Perspectives on Current Trends and Issues in Technical and Vocational Education and Training (TVET) in Africa" International Journal of Educational Development 27 (2): 220-234. 2007.

[10] W, Stephen., "Human Resource Development Through Vocational Education in the United Arab Emirates: The Case of Dubai Polytechnic." Journal of Vocational Education and Training 54 (1): pp.5-26. 2002.

[11] K, Kenneth., "The Geopolitics and Meanings of India's Massive Skills Development Ambitions" International Journal of Educational Development 32 (5): pp. 665-673. 2012.

[12] Finegold, David, Karin Wagner, and Geoff Mason. "National Skill-creation Systems and Career Paths for Service Workers: Hotels in the United States, Germany and the United Kingdom" International Journal of Human Resource Management 11 (3): pp. 497-516. 2000.

[13] Stevenson. J. (ed) Developing Vocational Expertise. Principles and issues in vocational education. Allen \& Unwin 83 Alexander Street Crows Nest 2065 Australia. 2003.

[14] Markowitsch, J. and and Hefler, G., "Staying in the Loop: Formal Feedback Mechanisms Connecting Vocational Training to the World of Work in Europe:. International Journal for Research in Vocational Education and Training (IJRVET). Vol. 5, Issue 4, December 2018,pp. 285-306. 2018.

[15] Billet, S. "Vocational Education. Purposes, Traditions and Prospects. Springer Science+Business Media B.V. Mount Gravatt Campus 4112 Griffith Queensland Australia”, International Journal of Vocational and Technical Education Research Vol.5, No.2, pp.1-23, April 2019.

[16] S. Prawiroo Harjo., "Policy Contributions to Increasing the Number of SMK Students to Indonesian Economic Development" in the Education Horizon, UNY: Educational Journals, pp. 301-331, 2017.

[17] M. Efendy.in SMK Bisa Hebat Magazine, $2^{\text {nd }}$ Edition. 2016.

[18] Presidential Instruction of Republic Indonesia No. 9 of 2016 about Revitalization of Vocational School to Enhance A Quality and Competitiveness of Human Resource.
[19] Noor. I,. Laskar, S,. Imanuddin, F., "Job Satisfaction to Enhance A Commitment Of Employees' Organization at Dream Tour and Travel Company", International Journal of Education, Learning and Development European Centre for Research Training and Development

$U K$ (www.eajournals. org. Vol.6, No.3, pp.4759, March 2018.

[20] Slameto..Learning and its Influencing Factors. Jakarta: Rineka Cipta. 2010.

[21] B. Walgito., Introduction to General Psychology, Yogyakarta: Andi Ofset. 2010

[22] Z Z. Firdaus,, "The effect of Production Unit, Internship and Family Support on Work Readiness of SMK Students". Journal of Vocational Education, vol 2, no.3, pp. 397409, 2012.

[23] Hana "The Effect of Internship Experiences and Locus of Control on Work Readiness of Class XII Students of SMK Negeri 1 Surakarta". J. l Jupe UNS, vol.1, no. 1, p. 86, 2013.

[24] Andreas Hirschi and Damian Läge. Holland's Secondary Constructs of Vocational Interests and Career Choice Readiness of Secondary Students Measures for Related but Different Constructs. Journal of Individual Differences. Switzerland. Hogrefe \& Huber Publishers Vol. 28(4). Pp. 205-218, 2007[25] Directorate of Vocational School. Implementation Guidelines for Internship of Vocational Schools, Jakarta: Dikmenjnur. 2016b

[26] N. Eko. "Industrial Work Practice (Internship) and its Contributions to Work Readiness of Class XII Students of SMK Negeri 1 Pati”. Economic Education Analysis Journal ISSN 2252-6544. 2015.

[27] O. Hamalik., Human Resources Development, Management of Employment Trainings, Integrated Approach. Jakarta: Bumi Aksara. 2007.

[28] A. Mulyadi,. "The effectiveness of industrial work practice in accordance with the demands of the workplace," Thesis of Mechantronics Education Study Program, Faculty of Engineering, UNY, 2014/

[29] W. Djojonegoro, Human Resources Development through Vocational Schools (SMK). Jakarta: PT Jayakarta Agung Offset. 1998.

[30] Teck Heang Lee "Perceived Job Readiness of Business Students at the Institutes of Higher Learning in Malaysia" International Journal of 
Advances in Management and Economics. Malasyia: Issue 6 Vol.1. p.151. 2012.

[31] Aminuddin \& M. Najib."Relationship of job involvements on vocational school students' job satisfactions in industrial training" International Journal of Vocational and Technical Education. Malasyia: Academic Journals Vol.5(1). p/p 1-7. 2013.

[32] I/ M. Sirsa "Contributions of Career Expectations, Work Motivation, and Internship Experiences to Work Readiness of Class XII Students of SMK Negeri 2 Seririt". E-Journal of the Post Graduate Program at Ganesha Education University, Study

Program of Education Administra-tion. Singaraja: vol. 5, 2014.

[33] E. Kochung., "Factors Influencing Students Career Choices among Secondary School Students in Kusuma Municipality". Kenya JETERAPS. Kenya: ISSN: 2141-6990. 2011.

[34] N. Fattah., Foundation of Educational Management. Bandung: Remaja Rosdakarya. 2009.

[35] H.. Uno., Theory of Motivation and its Measurement. Jakarta: Bumi Aksara. Wena, 2014.

[36] Tan Shen Kian,. "Job Satisfaction and Motivation: What Are The Difference Among These Two?'. Europen Journal of Business and Social Sciences. Eroupe: ISSN 2235-767X Vol. 3 No. 2. p.95, 2014

[37] Yuli. "Evaluation of the Implementation Industrial Work Practice of SMK Students in Agricultural Extension Skill Competence in South Kalimantan". Thesis, Yogyakarta: UNY,. 2012.

[38] R.R. Irsani dan N. W., Hidajati” Worl45] Readiness and Subject of Software Drafting in TGB (Drafter) Competency Program in di SMK Negeri 5 Surabaya" 2017

[39] A.S., Pramono. "The Effect of Industrial Work Practice to the Work Readiness of Class XII Students majoring in Building Drawing Engineering SMK Negeri 6 Malang," Thesis, Study Program of Building Engineering Education, Department of Civil Engineering, Faculty of Engineering, State University of Malang. 2017

[40] N. Huda.. "The Influence of Productive Subjects, Industrial Work Practices and Family
Economic Condition on Work Readiness of Class XI Students Majoring in Bulding, Department of Building Drawing Engineering, SMK Negeri 4 Semarang in 2014/2015 Academic Year". Thesis of Civil Engineering Department. Faculty of Engineering, UNNES, 2015.

[41] B. Prasetyo. and Darmono, "Evaluasi Pelaksanaan Praktik Kerja Industri Kompetensi Keahlian Teknik Gambar Bangunan SMK Negeri 2 Klaten", E-jurnal Pendidikan Teknik Sipil dan Bangunan Vol 2. No 1,2014). 2014.

[42\} M.A. Fauzi., "Readiness of Class XI Students of Building Drawing Engineering Skill Competence in SMK Negeri 2 Depok in Facing the Workplace, Academic Year of 2013/2014". Thesis, Faculty of Engineering of UNY. 2013. [43] N.N.R.P. Sanskia., "Work Readiness of Prospective Graduates of SMK Islam 1 Blitar of Building Drawing Engineering Skill Competence to Construction Services Workplace". Thesis of Civil Engineering Department, Faculty of Engineering, State University of Malang, 2013.

[44] S. Prihatinto. "The Effect of Internship to Work Readiness of Class XII Students in Building Drawing Engineering Skill Competence of SMKN 1 Adiwerna Tegal Academic Year of 2008/2009". Thesis, Semarang: Civil Engineering Department, UNNES. 2009.

[45] E. N, Mardiana,, "The Influence of Industrial Work Practice to the Work Readiness of Class XII Students of SMKN 5 Bandung. Indonesian Education University. repository. upi.edu/perpustakaan.upi.edu 2013 downloaded on 16 October 2017

\section{ACKNOWLEDGEMENTS}

The author is grateful to the Jakarta Office of Educational Research and Development for funding this study, the East Java Provincial Educational Office for the recommendation to allow the schools in the area to participate in this study. The deeply thankful is also address to the 5 and 7 Surabaya Vocational Secondary Schools who have participated and shared the experiences during the study conducted. 